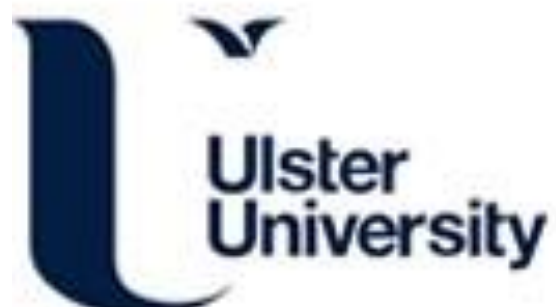

\section{Non-domestic phosphorus release in rivers during low-flow: Mechanisms and implications for sources identification}

Dupas, R., Tittel, J., Jordan, P., Musolff, A., \& Rode, M. (2018). Non-domestic phosphorus release in rivers during low-flow: Mechanisms and implications for sources identification. Journal of Hydrology, 560,141 - 149. https://doi.org/10.1016/j.jhydrol.2018.03.023

Link to publication record in Ulster University Research Portal

\section{Published in:}

Journal of Hydrology

Publication Status:

Published online: 12/03/2018

DOI:

10.1016/j.jhydrol.2018.03.023

\section{Document Version}

Author Accepted version

\section{General rights}

Copyright for the publications made accessible via Ulster University's Research Portal is retained by the author(s) and / or other copyright owners and it is a condition of accessing these publications that users recognise and abide by the legal requirements associated with these rights.

\section{Take down policy}

The Research Portal is Ulster University's institutional repository that provides access to Ulster's research outputs. Every effort has been made to ensure that content in the Research Portal does not infringe any person's rights, or applicable UK laws. If you discover content in the Research Portal that you believe breaches copyright or violates any law, please contact pure-support@ulster.ac.uk. 


\section{Non-domestic phosphorus release in rivers during low-flow: 2}

3

4 Rémi Dupas ${ }^{1,5^{*}}$, Jörg Tittel ${ }^{2}$, Phil Jordan ${ }^{3}$, Andreas Musolff $^{4}$, Michael Rode $^{1}$

$5{ }^{1}$ Department Aquatic Ecosystem Analysis, UFZ - Helmholtz-Centre for Environmental Research,

6 Magdeburg, Germany

$7 \quad{ }^{2}$ Department Lake Research, UFZ - Helmholtz-Centre for Environmental Research, Magdeburg,

8 Germany

$9{ }^{3}$ School of Environmental Sciences, University of Ulster, Coleraine, Northern Ireland, United Kingdom

$10{ }^{4}$ Department Hydrogeology, UFZ - Helmholtz-Centre for Environmental Research, Germany

$11{ }^{5}$ INRA UMR SAS, 65 route de Saint-Brieuc, 35042 Rennes, France

12 * Corresponding author: Rémi Dupas, remi.dupas@inra.fr 


\section{Abstract:}

A common assumption in phosphorus $(\mathrm{P})$ load apportionment studies is that $\mathrm{P}$ loads in rivers consist of flow independent point source emissions (mainly from domestic and industrial origins) and flow dependent diffuse source emissions (mainly from agricultural origin). Hence, rivers dominated by point sources will exhibit highest $\mathrm{P}$ concentration during low-flow, when flow dilution capacity is minimal, whereas rivers dominated by diffuse sources will exhibit highest $\mathrm{P}$ concentration during high-flow, when land-to-river hydrological connectivity is maximal. Here, we show that Soluble Reactive $\mathrm{P}$ (SRP) concentrations in three forested catchments free of point sources exhibited seasonal maxima during the summer low-flow period, i.e. a pattern expected in point source dominated areas. A load apportionment model (LAM) is used to show how point sources contribution may have been overestimated in previous studies, because of a biogeochemical process mimicking a point source signal. Almost twenty-two years (March 1995 - September 2016) of monthly monitoring data of SRP, dissolved iron (Fe) and nitrate-N (NO3) were used to investigate the underlying mechanisms: SRP and Fe exhibited similar seasonal patterns and opposite to that of NO3. We hypothesise that Fe oxyhydroxide reductive dissolution might be the cause of SRP release during the summer period, and that NO3 might act as a redox buffer, controlling the seasonality of SRP release. We conclude that LAMs may overestimate the contribution of $P$ point sources, especially during the summer low-flow period, when eutrophication risk is maximal.

\section{Keywords:}

Soluble reactive phosphorus, iron, redox processes, catchment, point source, load apportionment 


\section{Introduction}

Phosphorus (P) concentration in freshwater bodies is an important controlling factor of eutrophication worldwide (Smith and Schindler, 2009). Hence, national and federal regulations, such as the European Water Framework Directive (Directive 2000/60/EC), attach much importance to the reduction of $\mathrm{P}$ emissions to streams and rivers. Cost-effective alleviation of $\mathrm{P}$ emissions requires precise estimation of the contribution of different $\mathrm{P}$ sources in catchments to prioritise management efforts (Bowes et al., 2014; Jarvie et al., 2013b; Withers et al., 2014b).

Point source emissions, mainly from domestic and industrial origins, consist of direct P delivery into the river system. Diffuse source emissions, mainly from agricultural origin, result from the mobilisation of P sources distributed over the landscape and their delivery to rivers (Haygarth et al., 2005). In the case of point source emissions, P delivery from large waste water treatment plants can be monitored directly, but direct assessment of septic tanks leaking in rural areas requires detailed surveys or use of costly fingerprinting techniques (Arnscheidt et al., 2007; Neal et al., 2010; Richards et al., 2016). As an alternative, indirect methods have been developed to determine the relative contribution of point source and diffuse source emissions based on observed concentrationdischarge relationships (Bowes et al., 2008, 2014; Greene et al., 2011; Jarvie et al., 2012). These load apportionment models (LAMs) can take different forms, but rely on the same assumptions: point emissions are assumed to be constant in time while diffuse emissions are assumed to increase with discharge, as a result of increasing $\mathrm{P}$ mobilisation and delivery during runoff events (Bowes et al., 2015). The point source contribution to $P$ concentration is thus modelled as a linear function of the inverse of discharge (dilution effect) and several equations have been proposed to describe increasing diffuse $P$ concentration during high flow. For example, Bowes et al. (2008) proposed a power function of discharge, and Greene et al. (2011) proposed a linear combination of discharge and the square of discharge. To account for the temporary retention of $\mathrm{P}$ during low-flow and its remobilisation during high flow, and not to attribute all the remobilised $\mathrm{P}$ to diffuse sources, Jarvie et 
al. (2012) proposed an improved version of LAMs using chloride as a conservative tracer of wastewater effluents. In summary, LAMs belong to a large family of empirical models used to fit water quality time series (Minaudo et al., 2017; Moatar et al., 2017; Zhang and Ball, 2017) with the characteristic that they make an explicit distinction between flow dependent and flow independent pollution emissions.

The estimated contribution of point and diffuse sources to annual P loads vary according to the area (Jarvie et al., 2010), but even in catchments where diffuse emissions dominate annual loads, it is common to observe that point source emissions dominate daily $\mathrm{P}$ loads during a majority of the time (Greene et al., 2011; Serrano et al., 2015; Sharpley et al., 2009; Shore et al., 2017). Another consequence is that the summer low-flow season is assumed to be dominated by point emissions where they occur and are coincident to known point source pressures (Jordan et al., 2007, 2012; Withers et al., 2014a). Also, because this season is when light and temperature conditions are favourable to eutrophication, river basin managers might decide to target point sources as a priority to mitigate river eutrophication problems in a cost-effective manner (Jarvie et al., 2006; Shore et al., 2017; Stamm et al., 2014).

However, the low-flow period also corresponds to the warm summer season in catchments of the temperate zone, and it is well known that the biogeochemical processes influencing the $\mathrm{P}$ cycle in soils and river sediments are temperature dependent (Withers and Jarvie, 2008). In this paper, we hypothesised that temperature dependent biogeochemical processes could lead to $\mathrm{P}$ release to rivers during the summer low-flow period and that this release might be unduly attributed to point source emissions in load apportionment studies. To test this hypothesis, three rivers draining small forested catchments free of any point sources were investigated over a 22-year period to: i) quantify the seasonal variability of Soluble Reactive P (SRP) concentration and other solutes, ii) determine if previous $\mathrm{P}$ LAMs can be misrepresented by the seasonal dynamics observed, and iii) identify the controlling factors of this seasonal dynamics in order to improve future LAMs. 


\section{Materials and methods}

\subsection{Study area}

The Carlsfeld reservoir is located in eastern Germany, in the federal state of Saxony (Figure 1). Its catchment area is $5 \mathrm{~km}^{2}$ and spans both sides of the German - Czech border. Climate is temperate continental, with mean \pm standard deviations of annual precipitation and temperature of $1237.0 \pm$ $273.0 \mathrm{~mm}$ and $5.7 \pm 1.0^{\circ} \mathrm{C}$, respectively $(1995-2015)$. Mean monthly temperature varies from $-3.0 \pm$ $4.4^{\circ} \mathrm{C}$ in January to $14.4 \pm 3.8^{\circ} \mathrm{C}$ in July $(1995-2015)$. The catchment is located in a low-mountain range, the Ore Mountains, with elevations ranging from 904 to $971 \mathrm{~m}$. The geology is dominated by granite capped by podsols (classified as "well drained") in the upslope domain and organic gleysols (classified as "poorly drained") in valley-bottoms. Both dominant soil types were classified as "very acidic" ( $\mathrm{pH}<5)$, according to the German soil classification (DBK Sachsen, 1:50.000).

Three independent sub-catchments were selected for this study: Carlsfeld 1, $1.8 \mathrm{~km}^{2}$; Carlsfeld 2, 0.6 $\mathrm{km}^{2}$ and Carlsfeld $3,0.6 \mathrm{~km}^{2}$ (Figure 1). Their topography is gentle with an average slope of $3^{\circ}$ in each of the sub-catchments. The percentage of organic gleysols was $58.2 \%$ in Carlsfeld $1,44.4 \%$ in Carlsfeld 2 and 50.2\% in Carslfeld 3. Land use was 100\% forest (spruce) without any agriculture or human dwellings. Hence, the three study sub-catchments are free of any point source emissions to the streams and any fertiliser application on the land surface. 


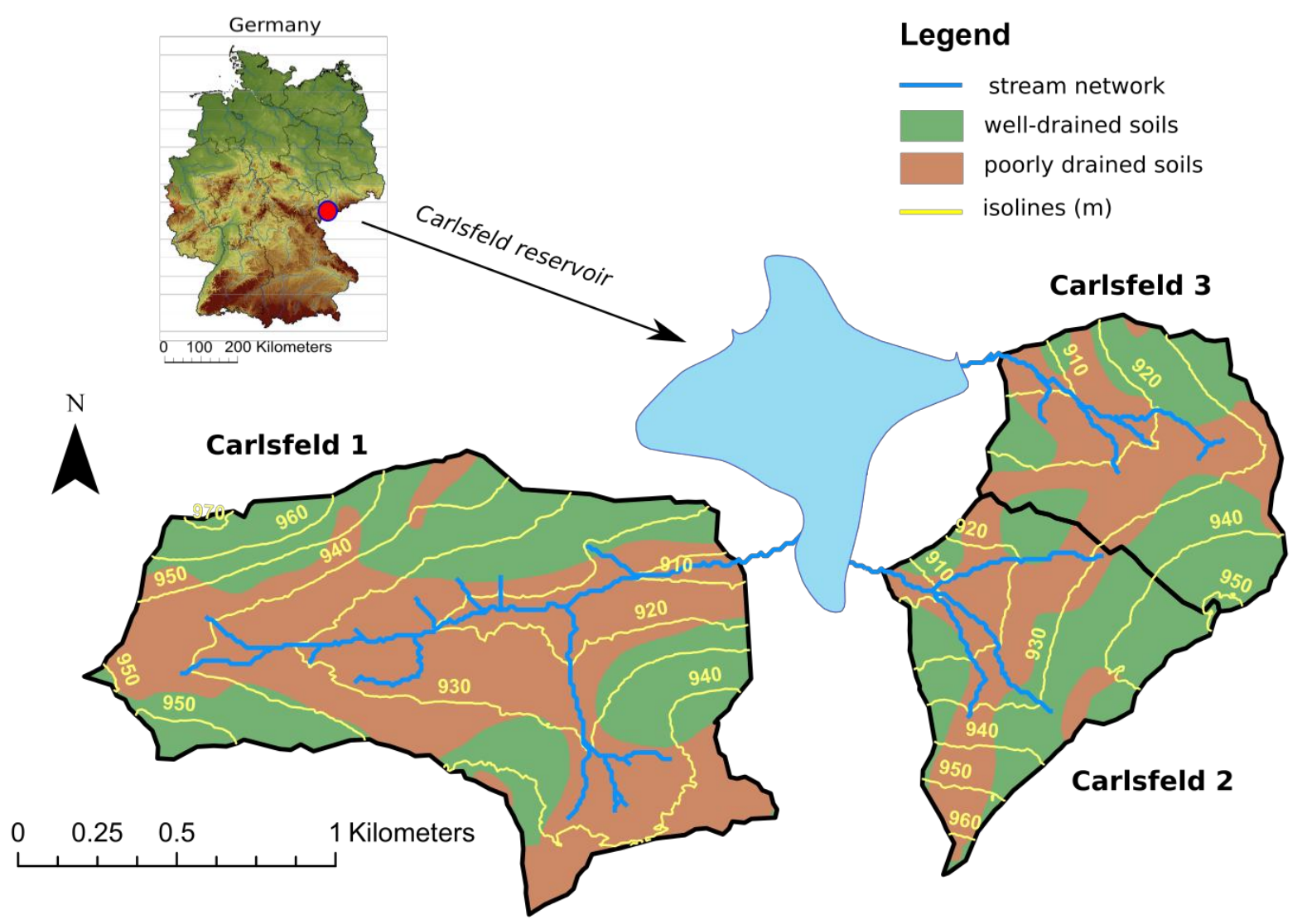

\section{Legend}

101

Figure 1: Localisation of the Carlsfeld reservoir and soil types in the three study catchments

\subsection{Hydro chemical monitoring}

The total discharge into the Carlsfeld reservoir was estimated daily from a mass balance calculation involving 15 min record of the reservoir water level (aggregated on a daily basis) and daily record of outflowing discharge. It was assumed that all three sub-catchments had the same specific discharge (in $\mathrm{mm} \mathrm{d}^{-1}$ ), equal to the specific discharge estimated for the whole catchment area of the reservoir.

This assumption was considered acceptable because the total catchment area was small, with similar topography and the same land use over the sub-catchments. Discharge data were available for the whole study period (March 1995 to September 2016) except from June 1997 to November 1999

(Figure 2).

Grab samples were collected monthly from March 1995 to September 2016, at the outlet of the three sub-catchments, between 8:00 am and 12:00 pm local time, and analysed for Soluble Reactive Phosphorus (SRP), nitrate-N (NO3) and dissolved Fe after $0.45 \mu \mathrm{m}$ filtration (Figure 2). Chemical 
analyses of water samples were performed using standard protocols (Wasserchemische Gesellschaft, 2014). SRP was determined colorimetrically by reaction with ammonium molybdate (UV-VIS Specord 200); NO3 was determined as N by ionic chromatography (ICS-1100 Dionex); Fe was determined by atomic absorption spectrometry (AAS Solaar M5, Thermo).

The three studied catchments have been previously included in two multi-site biogeochemical studies (Musolff et al., 2016; Sucker et al., 2011). A shorter time series of Carlsfeld 1 has also been selected for a showcase analysis of long-term Dissolved Organic Carbon (DOC) and SRP trends in Musolff et al., (2016), and in a DOC load uncertainty evaluation study (Buettner and Tittel, 2013). In contrast to the previously published biogeochemical studies, the present paper focuses on seasonal SRP variations and their implications for LAM.

\subsection{Data analysis}

The data analysis was threefold.

- The seasonal component of concentration and discharge time series was extracted from a long term trend component using Generalised Additive Models (GAM). GAM are generalized linear models in which the linear form is replaced by a sum of smooth functions (Hastie and Tibshirani, 1987). Technically, the year (1995-2016) and the month (1-12) for each data point were used as predictor variables to estimate the long term non-linear trend and a seasonal component, respectively. The R package $\operatorname{mgcv}$ (Wood, 2006) was used for this purpose, with cyclic cubic spline to avoid discontinuities at the end points of the spline (in other words, no discontinuity between December and January) and a correction for autocorrelation (autoregressive-moving-average model).

- The significance of trends was quantified by the slope of a linear regression model of annual mean concentration and discharge values as a function of the year. Although the GAM long term trend was not perfectly linear (see results), analysis of residuals showed that a linear model was acceptable to quantify a mean percentage increase or decrease during the study 
period and whether this increase or decrease was significant $(p<0.05)$. Only fully monitored years were considered here, i.e. from 1996 to 2015 for concentration data, and 1996 and from 2000 to 2015 for discharge. Percentage exceedance of an indicative SRP eutrophication threshold of $0.02 \mathrm{mg} \mathrm{SRP} \mathrm{I}^{-1}$ (EC, 2002) was estimated for the first ten full years of study (1996-2005) and the last ten full years of study (2006-2015). each pair of solutes were drawn. A LAM was fitted to the SRP-Q plots, to test whether the observed SRP-Q relationships in catchments without point source emissions could mimic a point source signal. Here the simplest version of the LAM was selected:

$$
S R P=\frac{a}{Q}+b * Q^{c}
$$

where $\frac{a}{Q}$ is the "virtual" contribution of point sources and $b * Q^{c}$ is the contribution of diffuse sources. The $a$ and $b$ parameters were constrained to be $>0$ and the $c$ parameter was constrained to be $>=1$. A nonlinear least-squares estimate of the parameters was determined with the nls() function in the R software (R Development Core Team, 2008). The "virtual" contribution of point sources on annual SRP load and the percentage of the time when "virtual" point sources dominated were estimated separately for the first ten full years of study (1996-2005) and the last ten full years of study (2006-2015). Also for the first ten years and the last ten years of study, alternative empirical (linear) models based on identified SRP controlling factors (see result section 3.2.) were tested and compared. For this comparison the LAM was used without a power law function to allow comparison with other

\section{Results}


Mean ( \pm standard deviation) annual SRP and dissolved Fe concentrations in Carlsfeld $1(13.1 \pm 3.5 \mu \mathrm{g}$ $\left.\mathrm{Pl}^{-1} ; 0.92 \pm 0.16 \mathrm{mg} \mathrm{Fe}^{-1}\right)$ and Carlsfeld $3\left(19.9 \pm 5.3 \mathrm{\mu g} \mathrm{P}^{-1} ; 0.91 \pm 0.17 \mathrm{mg} \mathrm{Fe} \mathrm{I}^{-1}\right)$ were significantly higher than in Carlsfeld $2\left(7.6 \pm 1.8 \mu \mathrm{g} \mathrm{P}^{-1} ; 0.44 \pm 0.07 \mathrm{mg} \mathrm{Fe}^{-1}\right)$ (paired Wilcoxon test, $\mathrm{p}<0.05$, $\mathrm{n}=20)$. Conversely, mean annual NO3 concentration in Carlsfeld $1\left(0.38 \pm 0.14 \mathrm{mg} \mathrm{N}^{-1}\right)$ and Carlsfeld $3\left(0.34 \pm 0.12 \mathrm{mg} \mathrm{N}^{-1}\right)$ was significantly lower than in Carlsfeld $2\left(0.46 \pm 0.11 \mathrm{mg} \mathrm{N} \mathrm{I}^{-1}\right)$. Differences between Carlsfeld 1 and Carlsfeld 3 were also significant for SRP and NO3 but not for Fe, and the differences between Carlsfeld 1 and Carlsfeld 3 were generally smaller than between Carlsfeld 1 or 3

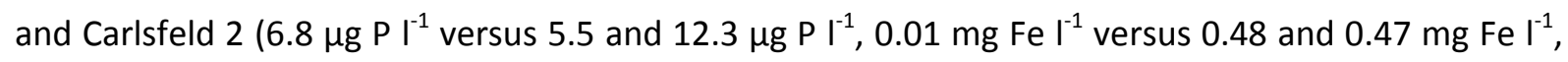
$0.04 \mathrm{mg} \mathrm{N}^{-1}$ versus 0.08 and $0.12 \mathrm{mg} \mathrm{N} \mathrm{I}^{-1}$, respectively).

From 1996 to 2015, mean annual SRP concentration increased significantly (linear model, $p<0.05$, $\mathrm{n}=20$ ) in the three catchments ( $+121 \%$ in Carlsfeld $1,+72 \%$ in Carlsfeld 2 and $+106 \%$ in Carlsfeld 3 ). In Carlsfeld 1 and Carlsfeld 3, significant increases in the mean annual concentration of dissolved Fe (+47 \% and $+62 \%$, respectively) were also observed, but not in Carlsfeld 2 ( $p>0.05)$. Conversely, mean annual NO3 concentration decreased significantly in the three catchments (-66 \% in Carlsfeld 1 , $-48 \%$ in Carlsfeld 2 and $-67 \%$ in Carlsfeld 3). No trend in mean annual discharge, precipitation or temperature could be detected from 1996 to 2015 (Figure S1), although the discharge long term trend appeared to decrease between 2012 and 2016 (Figure 2a).

Similar to the long-term trend, the seasonal dynamics of SRP and dissolved Fe mirrored that of NO3 (and discharge) in the three catchments: SRP and dissolved Fe reached their seasonal maximum in the late summer (August to October) which corresponded to the period with the lowest NO3 concentration and the lowest discharge (Figure $2 \mathrm{~b}$ ). Conversely, NO3 reached its seasonal maximum during the high flow period (March to May). The SRP and dissolved Fe seasonal dynamics and trends also seemed to be dependent on $\mathrm{NO} 3$ values and $\mathrm{NO} 3$ decreasing trends: in Carlsfeld 2, where NO3 concentrations were the highest and NO3 decreasing trend was the lowest, the seasonal amplitude 
187 of the dissolved Fe and SRP signal was weaker than in Carlsfeld 1 and 3, where NO3 concentrations

188 were lower and NO3 decreasing trends were stronger (Figure 2).

189 The number of months for which SRP concentration exceeded the indicative eutrophication 190 threshold of $0.02 \mathrm{mg} \mathrm{I}^{-1}$ increased for two of the three study catchments, between the first ten full 191 years of record (1996-2005) and the last ten full years of record (2006-2015). In Carlsfeld 1, this 192 threshold was exceeded $3 \%$ of the time during the first period and $24 \%$ of the time during the second 193 period. In Carlsfeld 3, the threshold was exceeded $26 \%$ of the time during the first period and $53 \%$ of 194 the time during the second period. In Carlsfeld 2, exceedance represented less than $0.1 \%$ of the time 195 during both periods. The season at which this exceedance was observed in Carlsfeld 1 and 3 was 196 mainly the late summer period (Figure 2), i.e., a period where light and temperature conditions are 197 favourable for eutrophication. 

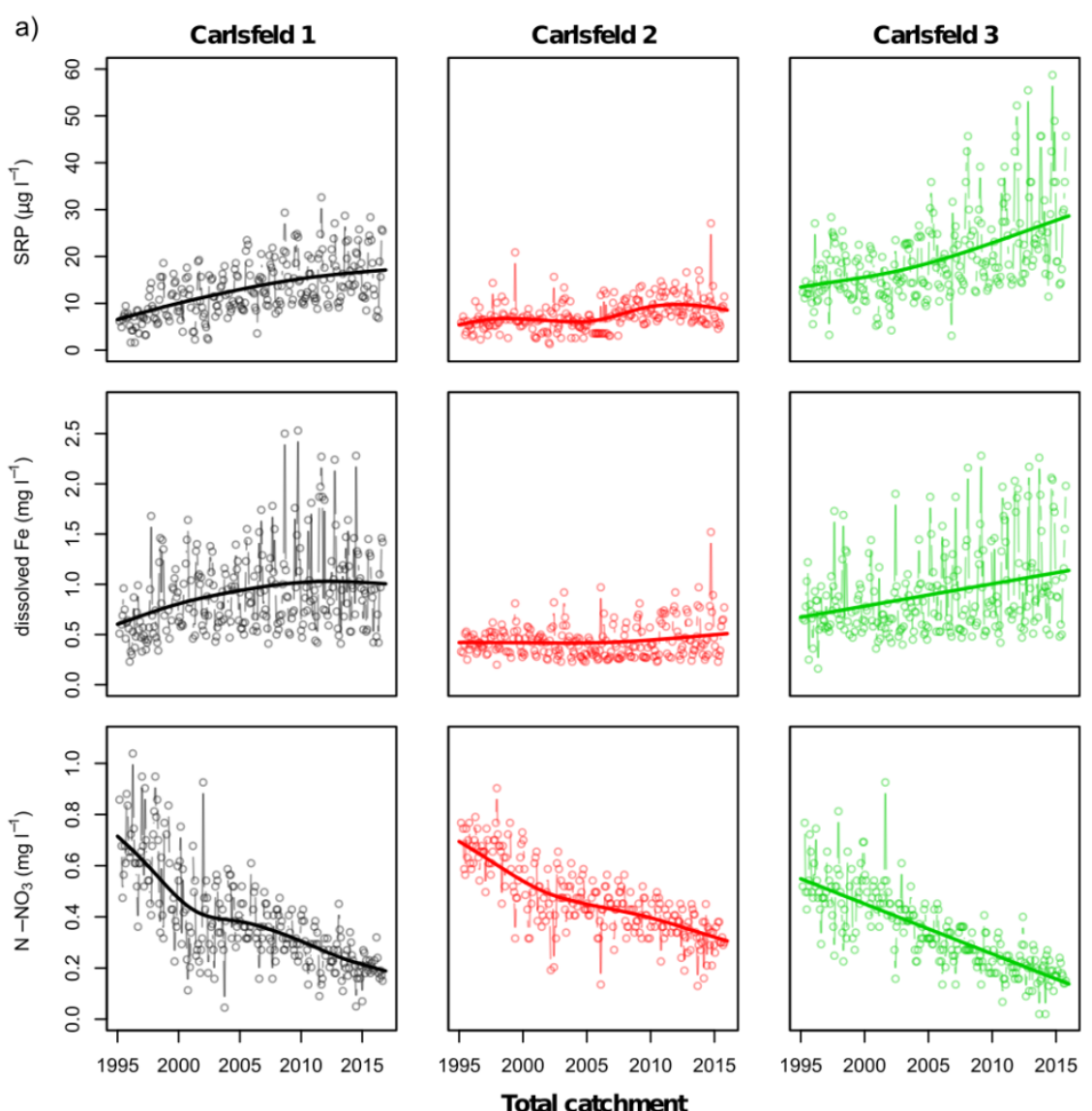

$1995200020052010 \quad 2015$

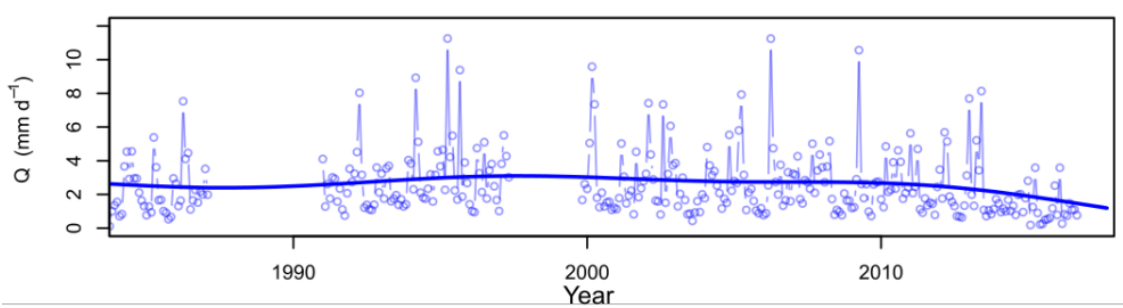

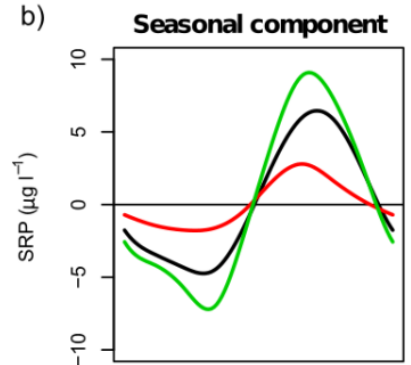
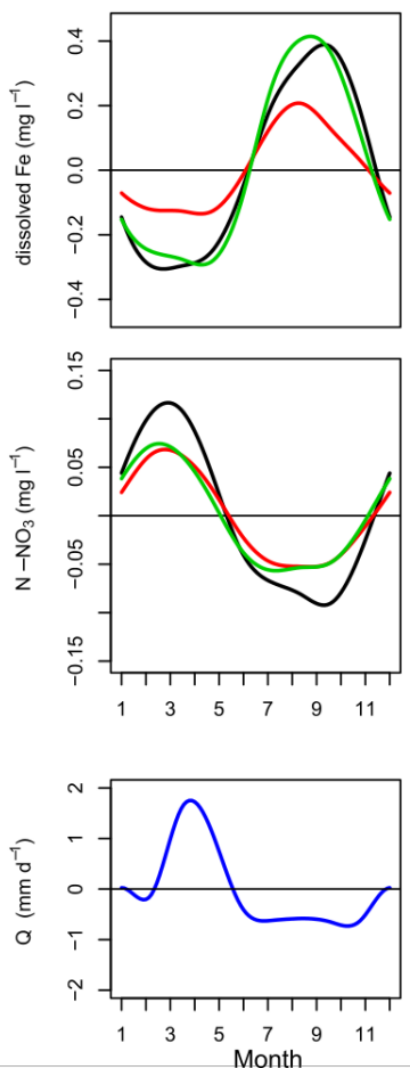

Figure 2: Monthly concentration and discharge data and long term components of GAM model (a) and seasonal component of GAM model (b). Open circles represent the original monthly time series and bold lines represent long term (a) and seasonal (b) GAM components.

\subsection{C-Q and C-C relationships}

None of the three solutes studied exhibited a clear and univocal relationship with discharge for the entire study period (1995-2016). Nitrate concentration was not significantly correlated with discharge ( $p>0.1)$ and SRP and dissolved Fe exhibited high concentrations both for the lowest and the highest discharge values (Figure S2). This lack of a clear relationship between concentrations and discharge is in apparent contradiction with the seasonal GAM component (Figure 2b), which shows that NO3 dynamics were in phase with discharge while SRP and dissolved Fe had opposite seasonal 
dynamics to discharge. However, the solutes were affected by large long term trends, and this was not the case for discharge; consequently, the $C-Q$ relationships changed from year to year and these relationships taken for the entire study period could not exhibit clear patterns.

Contrary to the C-Q plots, the C-C plot showed clear relationships between pairs of solutes (Figure 3), for the entire study period (1995-2016). Soluble reactive P was significantly $(p<0.05)$ correlated with Fe $(r=0.74-77)$, and both SRP and Fe exhibited a similar non-linear decreasing relationship with NO3, fitted with an exponential function in Figure 3.
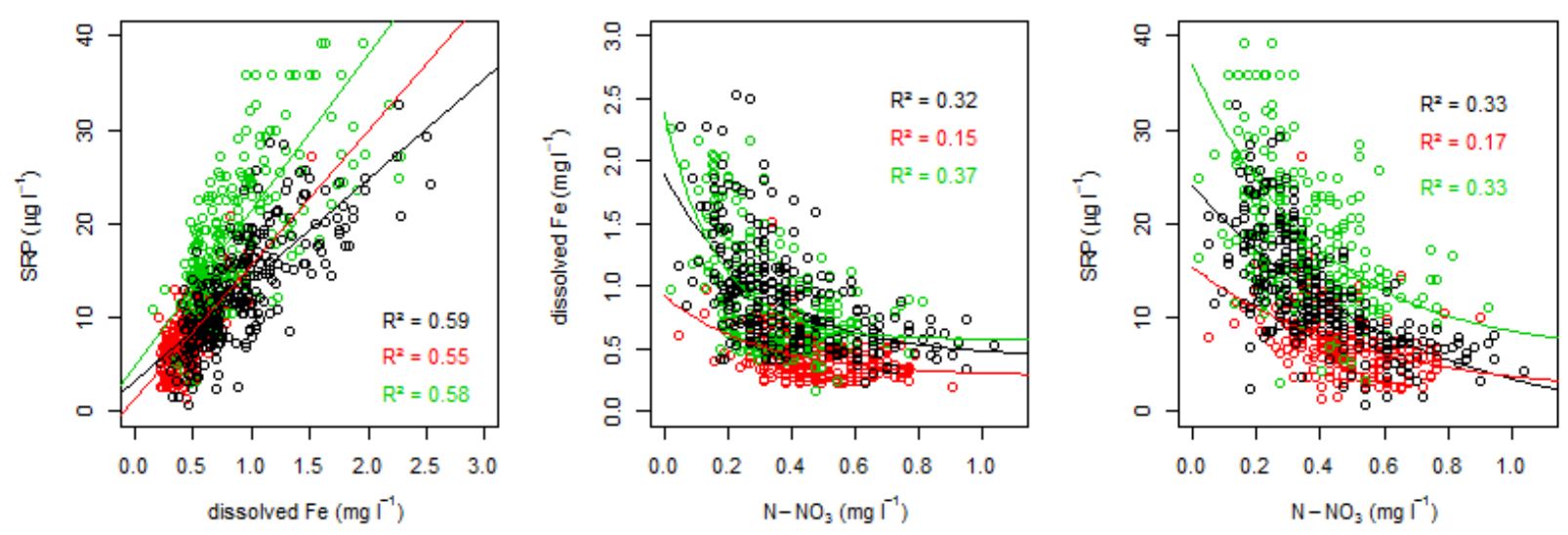

Figure 3: Concentration-concentration relationships between pairs of solutes. The relationship between SRP and dissolved iron was fitted with a linear model $y=a+b^{*} x$, and the relationship between NO3 and dissolved Fe and between NO3 and SRP was fitted with an exponential model $y=a+b^{*} \exp \left(-c^{*} x\right)$. Carlsfeld 1 in black, Carlsfeld 2 in red, Carlsfeld 3 in green.

According to the SRP-Q LAM (Figure 4), annual loads varied from 0.06 to $0.15 \mathrm{~kg} \mathrm{SRP} \mathrm{ha}^{-1} \mathrm{yr}^{-1}$ for all three catchments and for the two periods considered: prior to 2005 and after 2005. The differences between catchments reflected their different SRP concentrations visible in Figure 2, as specific discharge was assumed to be the same. Estimated loads were similar before and after 2005, but this result must be considered with care as the load estimation method is very sensitive (by construction) to the high flow data points, and the number of these may differ between the two periods.

227 Therefore, it would not be reasonable to split the 22 years into more than two periods to apply the LAM, as these models are very sensitive to the monitoring frequency and/or duration (Crockford et 
al., 2017). More interestingly, the estimated virtual contribution of point sources increased in the

230 three sub-catchments. In Carlsfeld 1, the virtual contribution of point sources increased from $10 \%$ to

$21 \%$ between the first ten years of study (1996-2005) and the last ten years (2006-2015), and this

virtual point sources contribution dominated daily loads during $70 \%$ and $84 \%$ of the time during the

two periods, respectively. In Carlsfeld 2, the virtual contribution of point sources increased from 7\%

to $13 \%$, and this virtual point sources contribution dominated daily loads during $62 \%$ and $73 \%$ of the

is also the period at highest eutrophication risk due to optimal light and temperature conditions.
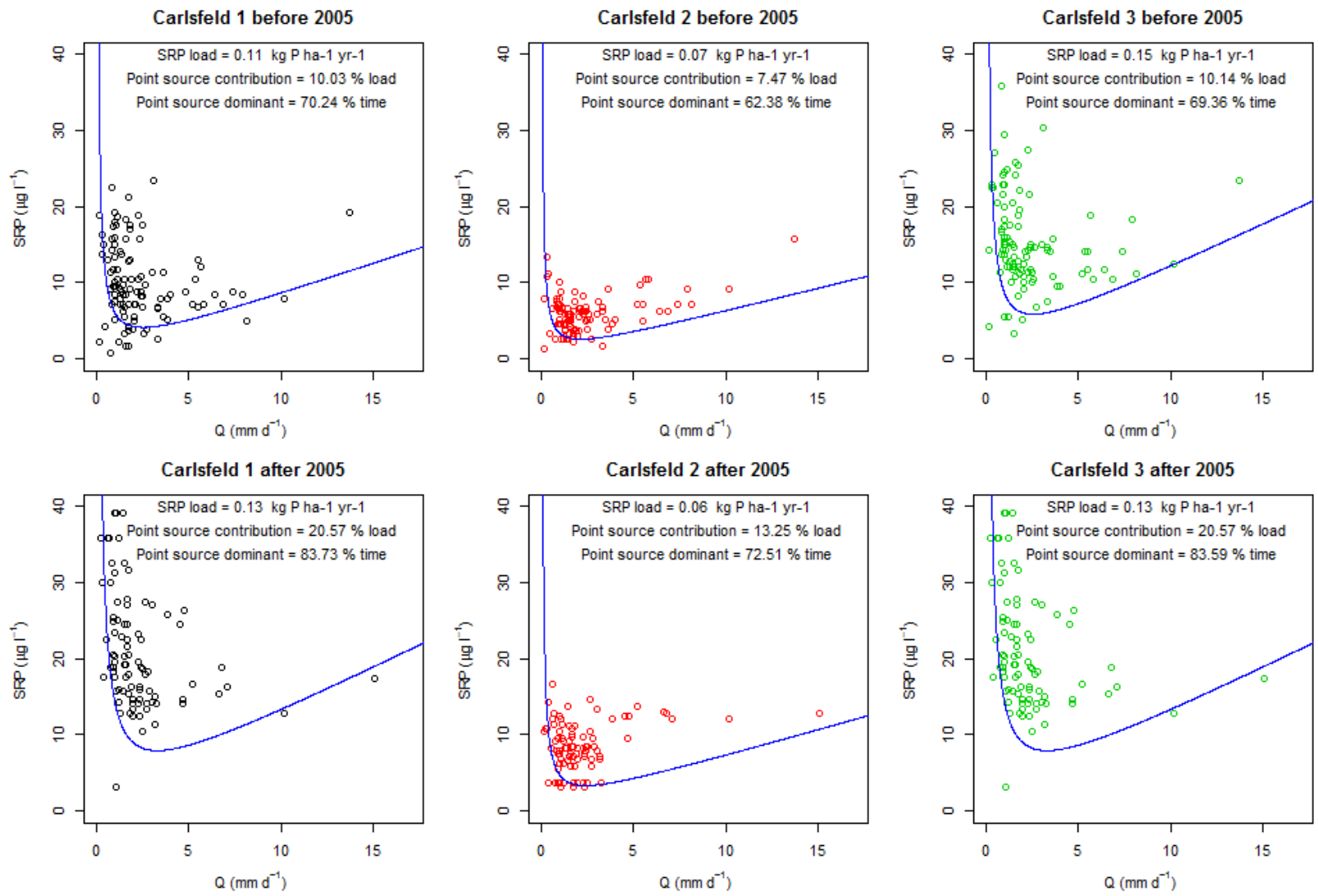


$$
\begin{aligned}
& \text { Carlsfeld1 (before 2005): } S R P=1.4 * 10^{-3}+1.1 * 10^{-2} * F e \\
& \text { Carlsfeld1 (after 2005): } S R P=6.1 * 10^{-3}+9.1 * 10^{-3} * F e \\
& \text { Carlsfeld2 (before 2005): } S R P=1.1 * 10^{-3}+1.2 * 10^{-2} * F e \\
& \text { Carlsfeld2 (after 2005): SRP }=3.0 * 10^{-3}+1.3 * 10^{-2} * F e \\
& \text { Carlsfeld3 (before 2005): SRP }=5.6 * 10^{-3}+1.3 * 10^{-2} * F e \\
& \text { Carlsfeld3 (after 2005): } S R P=7.4 * 10^{-3}+1.5 * 10^{-2} * F e
\end{aligned}
$$

With SRP and Fe in $\mathrm{mg} \cdot \mathrm{I}^{-1}$ and $\mathrm{Q}$ in $\mathrm{mm} \cdot \mathrm{d}^{-1}$.

The best model with two variables was the "biogeochemical model" + discharge $\left(R^{2}=0.92-0.93\right)$, in which the part of the equation corresponding to the dilution of a constant source in the LAM is replaced by a linear function of dissolved Fe.

Table 1: Comparison of the coefficient of determination $R^{2}$ for five linear models fitted to the first ten years of study (1996 - 2005) and the last ten years (2006-2015) of study in the Carsfeld sub-catchments.

\begin{tabular}{|c|c|c|c|c|c|c|c|}
\cline { 3 - 8 } \multicolumn{2}{c|}{} & \multicolumn{2}{c|}{$\mathrm{R}^{2}$ Carlsfeld 1 } & \multicolumn{2}{c|}{$\mathrm{R}^{2}$ Carlsfeld 2 } & \multicolumn{2}{c|}{$\mathrm{R}^{2}$ Carlsfeld 3 } \\
\hline$\underline{\text { model }}$ & model equation & before & after & before & after & before & after \\
\hline Dilution of a & 2005 & 2005 & 2005 & 2005 & 2005 & 2005 \\
constant & SRP 1/Q+ & 0.02 & 0.05 & 0.00 & 0.01 & 0.01 & 0.22 \\
source & intercept & 0.005 & & & & \\
\hline
\end{tabular}




\begin{tabular}{|c|c|c|c|c|c|c|c|}
\hline $\begin{array}{l}\text { Increasing } \\
\text { export with } \\
\text { discharge }\end{array}$ & $\begin{array}{l}S R P \sim Q+ \\
\text { intercept }\end{array}$ & 0.01 & 0.01 & 0.14 & 0.04 & 0.01 & 0.03 \\
\hline $\begin{array}{c}\text { Load } \\
\text { apportionmen } \\
\text { t model }\end{array}$ & $S R P \sim 1 / Q+Q$ & 0.64 & 0.57 & 0.79 & 0.58 & 0.66 & 0.62 \\
\hline $\begin{array}{l}\text { "Biogeochemi } \\
\text { cal model" }\end{array}$ & $\begin{array}{l}\text { SRP } \sim \mathrm{Fe}+ \\
\text { intercept }\end{array}$ & 0.59 & 0.64 & 0.37 & 0.57 & 0.47 & 0.56 \\
\hline $\begin{array}{l}\text { "Biogeochemi } \\
\text { cal model" + } \\
\text { increasing } \\
\text { export with } \\
\text { discharge }\end{array}$ & $\mathrm{SRP} \sim \mathrm{Fe}+\mathrm{Q}$ & 0.92 & 0.93 & 0.93 & 0.93 & 0.93 & 0.92 \\
\hline
\end{tabular}

\section{Discussion}

A recent study of SRP and DOC trends in 110 German catchments draining into drinking water reservoirs (including the 3 Carlsfeld sub-catchments) has documented a long term increase in SRP and DOC, associated with an increase in dissolved Fe and a decrease in $\mathrm{NO} 3$ in catchments with acidic soils (Musolff et al., 2016). The authors concluded that Fe oxyhydroxide reduction was the dominant mechanism explaining increased SRP and DOC release into streams and that NO3, being a stronger electron acceptor than Fe, acted as a redox buffer. According to this hypothesis, decreasing atmospheric $\mathrm{N}$ deposition could lead to a decrease in NO3 redox buffering capacity and this decrease is the main cause of the observed increasing SRP and DOC trends in these catchments. Our trend observations are compatible with the redox hypothesis, hence long term trends in the Carlsfeld subcatchment will not be discussed further in this paper. Rather, in section 4.1. we discuss whether the redox hypothesis and NO3 redox buffering could also explain the seasonal variability in SRP observed 
in the Carlsfeld sub-catchments. Also, in section 4.2., we discuss the implications of the observed SRP seasonal dynamics in terms of water quality assessment and management.

\subsection{Interplay of hydrological and biogeochemical processes}

Previous studies have demonstrated that variability in dominant flow pathways or in the contribution of several conceptual compartments with different chemical signatures exert a large control on SRP and NO3 concentrations in rivers (Mellander et al., 2012; Dupas et al., 2017a), and that this variability is influenced by changing hydroclimatic conditions on a seasonal or inter annual basis (Ockenden et al., 2016). In catchments with similar shallow groundwater systems and presence of riparian wetlands, the seasonal variability of SRP and NO3 has previously been explained by the high contribution of a riparian compartment (rich in SRP due to the shallow groundwater interacting with the organic soils and poor in NO3 due to denitrifying conditions) during the dry season, and by the high contribution of an upslope compartment (poor in SRP due to the deeper groundwater and richer in NO3 because of limited denitrification in well-drained soils) during the wet season (Dupas et al., 2016, 2017a; Exner-Kittridge et al., 2016; Martin et al., 2004; Woodward et al., 2013). Here, the fact that the two sub-catchments with substantially higher SRP concentrations, and lower NO3 concentration (Carlsfeld 1 and 3), are also those with the highest percentage of organic riparian soils (see section 2.1), supports previous assertions that organic riparian soils are internal sources of SRP (Dupas et al., 2017b; Gu et al., 2017; Records et al., 2016), and a buffer zone for NO3 (Anderson et al., 2014; Oehler et al., 2009). Other factors such as P speciation in soils may also play a role (Gu et al., 2017). However, a conceptual model relying only on the hydrological connectivity of two conceptual compartments with different chemical signatures is questionable, as all water flows pass through the riparian wetland and/or hyporheic zone and should, according to this conceptual model, lose NO3 through denitrification and gain SRP through interactions with organic soils regardless of the season. In this respect, the question of water residence time and temperature is crucial, in conjunction with an interpretation based on the mixing of conceptual compartments (Hrachowitz et al., 2016; Pinay et al., 2015). In the Carlsfeld sub-catchments, residence times in the riparian 
compartment were arguably too short during the wet period, when groundwater hydraulic gradients are maximal and flow velocity at their highest, and temperatures too low, for denitrification and SRP solubilisation to take place. The central role played by biogeochemical processes in SRP release mechanisms is illustrated by the $\mathrm{C}-\mathrm{C}$ relationships (Figure 3 ) which, contrarily to the $\mathrm{C}$-Q plots (Figure S2), appeared to be stable in the long term. The strong correlation between SRP and dissolved Fe, and the negative relationships between SRP or dissolved Fe with NO3 support the hypothesis of a dominant redox control on seasonal SRP release during the summer period (Li et al., 2012; Musolff et al., 2016; Smolders et al., 2017). Furthermore, sulphate concentrations and pH do not exhibit seasonal cycles in these catchments (Figure S3). Simultaneous release of ferrous Fe and SRP have been measured in-situ in riparian soils (Dupas et al., 2015; Gu et al., 2017; Surridge et al., 2007; van der Grift et al., 2014), and the same authors observed that NO3 could play the role of a redox buffer that determines the timing of Fe oxyhydroxides reductive dissolution and subsequent SRP release. Hence, the seasonal variability of NO3 inputs to the riparian wetland, with high inputs from the upslope nitrate rich compartment during the wet period and lower inputs combined with higher denitrification during the warmer summer period (Dupas et al., 2016; Exner-Kittridge et al., 2016; Woodward et al., 2013), could govern SRP seasonal dynamics via reductive desorption of SRP previously bound to Fe oxyhydroxides. Hydrology is both a proximate and ultimate control (e.g. Thomas et al., 2016) of the seasonal variability in SRP and NO3 in the streams of the Carlsfeld catchment.

The hypothesis of a dominant redox control on SRP and dissolved Fe dynamics is apparently contradicted by field observation in intensively farmed regions of Belgium and the Netherlands that phosphate and Fe oxyhydroxides usually co-precipitate during exfiltration of anoxic groundwater to oxic stream waters, and thus phosphate is retained within soils and sediments (Baken et al., 2015; van der Grift et al., 2014). However, Baken et al. (2016) have shown in the same region that instream water with a P:Fe molar ratio below 0.1, co-precipitation of phosphate and Fe oxyhydroxides was not leading to retention but instead could form mobile Fe-rich colloids which can be transferred 
to the streams. The mean and maximum P:Fe molar ratio in the three Carlsfeld sub-catchments ranged from 0.03 to 0.04 and 0.06 to 0.12 respectively, i.e. below or close to the threshold proposed by Baken et al. (2016). This means that with the relatively low SRP concentrations observed in the Carlsfeld sub-catchments, it is likely that Fe-rich colloids are the vector of $P$, and that these Fe-P colloids can still be measured as SRP (Gu et al., 2017; Sinaj et al., 1998; Van Moorleghem et al., 2011).

To conclude, a biogeochemical process releasing SRP during the summer period was identified: both a temperature control and a hydrological control, via residence times and NO3 influx to the riparian reactive zone, and are likely to explain the seasonal dynamics observed.

\subsection{Implications for water quality assessment and management}

The observed SRP dynamics has implications for water quality assessment. LAMs based on C-Q relationships might overestimate point source contributions in some contexts where there is a presence of point sources (i.e. the contexts where load apportionment models can usually be used), because a biogeochemical process releasing SRP during summer low-flow can augment the point source signal. This summer SRP release, exceeding $0.05 \mathrm{mg} \mathrm{I}^{-1}$ in one of the study catchments, is likely to have a significant impact on LAMs in many contexts where small point sources occur: for example in the TERENO Harz/Central German Lowland Observatory, a $3300 \mathrm{~km}^{2}$ area encompassing large gradients of land use and elevation in Central Germany and including small point sources, summer SRP concentrations range from $<0.01 \mathrm{mg} \mathrm{l}^{-1}$ to $0.12 \mathrm{mg} \mathrm{l}^{-1}$ (Kamjunke et al., 2013). Therefore, we recommend combining these C-Q LAMs with markers of effluent discharge and survey of point emissions, at least to test the method in catchments where point emissions are well identified and quantified (Arnscheidt et al., 2007; Neal et al., 2010; Richards et al., 2016). Error in source identification will have an impact on the cost-effectiveness of measures to remediate $P$ in rivers because managers might choose to target point sources as a priority, whereas diffuse source 
344 programmes targeting reduction of $\mathrm{P}$ inputs on agricultural land might be misled by the long term

345 SRP trend, controlled by processes independent from inputs, which could mask the effect of improved management practices within catchments.

Although the seasonal SRP dynamics can mimic a point source signal, as highlighted by the relatively good fit of the LAM, a better fit to the data was obtained with an empirical model including dissolved Fe as a predictor variable. However, the latter cannot be transferred to catchments where both the summer SRP release from riparian wetlands and point source emissions take place, because the dissolved Fe - SRP relationship established for the Carlsfeld sub-catchment will probably not be valid in other areas. It would, therefore, be necessary for further research to determine the controlling factor(s) of this dissolved Fe - SRP relationship (e.g. soil Fe and P content and speciation, hydrology, land use), as it could provide a basis for a new generation of LAMs that disentangle summer SRP release from riparian wetlands and point source emissions.

The observed SRP dynamics has implications for water quality management, because management options generally do not take into account the interactions between nitrogen and phosphorus. If the hypothesis of NO3 buffering SRP release is confirmed in catchments with higher anthropogenic pressures, remediation programmes targeting $\mathrm{N}$ as a priority might result in increasing SRP concentrations in streams and rivers. Even when both $\mathrm{N}$ and $\mathrm{P}$ are targeted by remediation programmes, the long term legacy of $P$ in soils (Jarvie et al., 2013a) might lead to a slow depletion of the $\mathrm{P}$ accumulated in the catchment as compared to $\mathrm{N}$, thus increased SRP release from riparian wetlands (in summer) is possible.

Further research is needed to determine if the hypothesis of NO3 buffering SRP release, followed by SRP delivery to streams, can take place also in agricultural catchments, where $\mathrm{N}$ inputs are much higher than in the study case presented here. The comparison of the three Carlsfeld sub-catchments suggests that redox mediated SRP release needs extremely low NO3 concentration to take place: in 
Carlsfeld 2, where SRP release seemed to be almost inhibited compared to Carlsfeld 1 and 3, the mean annual NO3 concentration was only $0.46 \pm 0.11 \mathrm{mg} \mathrm{N} \mathrm{I}^{-1}$, a concentration far below what is commonly measured in agricultural areas. However, redox mediated SRP release has been documented in some of the regions with the highest agricultural pressures in Europe such as Western France (Dupas et al., 2015; Gu et al., 2017), Belgium (Baken et al., 2016) and the Netherlands (van der Grift et al., 2014). Hence stream nitrate NO3 may not in isolation be a good indicator of redox mediated SRP release, as this process can take place in local organic rich hotspots where NO3 is absent, whereas in agricultural areas NO3 can still be high in deeper flow paths.

\section{Conclusions}

In this study, with direct implications for catchment management and monitoring programmes where eutrophication is an issue, we showed that:

- a biogeochemical process releasing SRP during summer low-flow can mimic a point source signal and may lead to overestimation of point source contributions in P load apportionment studies;

- a long term increasing SRP trend could possibly mask the effect of reduced P inputs in some areas;

- seasonal reductive dissolution of Fe oxyhydroxides is a probable mechanism for the summer SRP release from riparian wetland soils, under the control of temperature, residence times and NO3 influx.

Further methodological developments are necessary to include summer SRP release from riparian wetlands into LAMs, especially in rural areas where domestic $\mathrm{P}$ emissions are difficult to evaluate due to their scattered distribution throughout catchments. 
02WT1290A). We thank the State Reservoir Administration of Saxony for providing the chemical and

\section{References}

Anderson, T.R., Groffman, P.M., Kaushal, S.S., Walter, M.T., 2014. Shallow Groundwater Denitrification in Riparian Zones of a Headwater Agricultural Landscape. Journal of Environmental Quality, 43(2): 732-744. 10.2134/jeq2013.07.0303

Arnscheidt, J. et al., 2007. Defining the sources of low-flow phosphorus transfers in complex catchments. Science of the Total Environment, 382(1): 1-13. 10.1016/j.scitotenv.2007.03.036

Baken, S., Moens, C., van der Grift, B., Smolders, E., 2016. Phosphate binding by natural iron-rich colloids in streams. Water Research, 98: 326-333. 10.1016/j.watres.2016.04.032

Baken, S., Verbeeck, M., Verheyen, D., Diels, J., Smolders, E., 2015. Phosphorus losses from agricultural land to natural waters are reduced by immobilization in iron-rich sediments of drainage ditches. Water Research, 71: 160-170. 10.1016/j.watres.2015.01.008

Bowes, M.J. et al., 2015. Characterising phosphorus and nitrate inputs to a rural river using highfrequency concentration-flow relationships. The Science of the total environment, 511: 60820. 10.1016/j.scitotenv.2014.12.086

Bowes, M.J. et al., 2014. Identifying priorities for nutrient mitigation using river concentration-flow relationships: The Thames basin, UK. Journal of Hydrology, 517: 1-12. 10.1016/j.jhydrol.2014.03.063

Bowes, M.J., Smith, J.T., Jarvie, H.P., Neal, C., 2008. Modelling of phosphorus inputs to rivers from diffuse and point sources. Science of the Total Environment, 395(2-3): 125-138. 10.1016/j.scitotenv.2008.01.054

Buettner, O., Tittel, J., 2013. Uncertainties in dissolved organic carbon load estimation in a small stream. Journal of Hydrology and Hydromechanics, 61(1): 81-83. 10.2478/johh-2013-0010

Crockford, L. et al., 2017. The application of high temporal resolution data in river catchment modelling and management strategies. Environ. Monit. Assess., 189(9). 10.1007/s10661-017$6174-1$

Dupas, R. et al., 2015. Groundwater control of biogeochemical processes causing phosphorus release from riparian wetlands. Water Research, 84: 307-314. 10.1016/j.watres.2015.07.048

Dupas, R., S., J., Musolff, A., Borchardt, D., Rode, M., 2016. Disentangling the influence of hydroclimatic patterns and agricultural management on river nitrate dynamics from subhourly to decadal time scales. Science of the Total Environment(571): 791-800. 10.1016/j.scitotenv.2016.07.053

Dupas, R. et al., 2017a. The role of mobilisation and delivery processes on contrasting dissolved nitrogen and phosphorus exports in groundwater fed catchments. Science of the Total Environment(599-600): 1275-1287.

Dupas, R. et al., 2017b. Carbon and nutrient export regimes from headwater catchments to downstream reaches. Biogeosciences(14): 4391-4407.

EC, 2002. Eutrophication and health. Luxembourg Office for Official Publications of the European Communities 
Exner-Kittridge, M. et al., 2016. The seasonal dynamics of the stream sources and input flow paths of water and nitrogen of an Austrian headwater agricultural catchment. Science of the Total Environment, 542: 935-945. 10.1016/j.scitotenv.2015.10.151

Greene, S., Taylor, D., McElarney, Y.R., Foy, R.H., Jordan, P., 2011. An evaluation of catchment-scale phosphorus mitigation using load apportionment modelling. Science of the Total Environment, 409(11): 2211-2221. 10.1016/j.scitotenv.2011.02.016

$\mathrm{Gu}$, S. et al., 2017. Release of dissolved phosphorus from riparian wetlands: evidence for complex interactions among hydroclimate variability, topography and soil properties. Science of the Total Environment(598): 421-431.

Hastie, T., Tibshirani, R., 1987. Generalized additive-models - some applications. Journal of the American Statistical Association, 82(398): 371-386. 10.2307/2289439

Haygarth, P.M., Condron, L.M., Heathwaite, A.L., Turner, B.L., Harris, G.P., 2005. The phosphorus transfer continuum: Linking source to impact with an interdisciplinary and multi-scaled approach. Science of the Total Environment, 344(1-3): 5-14. 10.1016/j.scitotenv.2005.02.001

Hrachowitz, M. et al., 2016. Transit times-the link between hydrology and water quality at the catchment scale. Water

Jarvie, H.P., Neal, C., Withers, P.J.A., 2006. Sewage-effluent phosphorus: A greater risk to river eutrophication than agricultural phosphorus? Science of the Total Environment, 360(1-3): 246-253. 10.1016/j.scitotenv.2005.08.038

Jarvie, H.P. et al., 2012. Within-River Phosphorus Retention: Accounting for a Missing Piece in the Watershed Phosphorus Puzzle. Environmental Science \& Technology, 46(24): 13284-13292. 10.1021/es303562y

Jarvie, H.P. et al., 2013a. Water Quality Remediation Faces Unprecedented Challenges from "Legacy Phosphorus". Environmental Science \& Technology, 47(16): 8997-8998. 10.1021/es403160a

Jarvie, H.P. et al., 2013b. Phosphorus Mitigation to Control River Eutrophication: Murky Waters, Inconvenient Truths, and "Postnormal" Science. Journal of Environmental Quality, 42(2): 295304. 10.2134/jeq2012.0085

Jarvie, H.P. et al., 2010. Streamwater phosphorus and nitrogen across a gradient in rural-agricultural land use intensity. Agriculture Ecosystems \& Environment, 135(4): 238-252. 10.1016/j.agee.2009.10.002

Jordan, P., Arnscheidt, A., McGrogan, H., McCormick, S., 2007. Characterising phosphorus transfers in rural catchments using a continuous bank-side analyser. Hydrology and Earth System Sciences, 11(1): 372-381

Jordan, P., Melland, A.R., Mellander, P.E., Shortle, G., Wall, D., 2012. The seasonality of phosphorus transfers from land to water: implications for trophic impacts and policy evaluation. Sci Total Environ, 434: 101-9. 10.1016/j.scitotenv.2011.12.070

Kamjunke, N. et al., 2013. Biogeochemical patterns in a river network along a land use gradient. Environmental Monitoring and Assessment, 185(11): 9221-9236. 10.1007/s10661-013-32477

Li, Y.C., Yu, S., Strong, J., Wang, H.L., 2012. Are the biogeochemical cycles of carbon, nitrogen, sulfur, and phosphorus driven by the "Fe-III-Fe-II redox wheel" in dynamic redox environments? Journal of Soils and Sediments, 12(5): 683-693. 10.1007/s11368-012-0507-z

Martin, C. et al., 2004. Seasonal and interannual variations of nitrate and chloride in stream waters related to spatial and temporal patterns of groundwater concentrations in agricultural catchments. Hydrol. Process., 18(7): 1237-1254. 10.1002/hyp.1395

Mellander, P.-E. et al., 2012. Quantifying nutrient transfer pathways in agricultural catchments using high temporal resolution data. Environmental Science \& Policy, 24: 44-57. 10.1016/j.envsci.2012.06.004

Minaudo, C. et al., 2017. Nonlinear empirical modeling to estimate phosphorus exports using continuous records of turbidity and discharge. Water Resour. Res. 
Moatar, F., Abbott, B.W., Minaudo, C., Curie, F., Pinay, G., 2017. Elemental properties, hydrology, and biology interact to shape concentration-discharge curves for carbon, nutrients, sediment, and major ions. Water Resour. Res., 53(2): 1270-1287.

Musolff, A., Selle, B., Buettner, O., Opitz, M., Tittel, J., 2016. Unexpected release of phosphate and organic carbon to streams linked to declining nitrogen depositions. Global Change Biology: 111. 10.1111/gcb.13498

Neal, C., Jarvie, H.P., Withers, P.J.A., Whitton, B.A., Neal, M., 2010. The strategic significance of wastewater sources to pollutant phosphorus levels in English rivers and to environmental management for rural, agricultural and urban catchments. Science of the Total Environment, 408(7): 1485-1500. 10.1016/j.scitotenv.2009.12.020

Ockenden, M.C. et al., 2016. Changing climate and nutrient transfers: Evidence from high temporal resolution concentration-flow dynamics in headwater catchments. Science of the Total Environment, 548: 325-339. 10.1016/j.scitotenv.2015.12.086

Oehler, F., Durand, P., Bordenave, P., Saadi, Z., Salmon-Monviola, J., 2009. Modelling denitrification at the catchment scale. Science of the Total Environment, 407(5): 1726-1737. 10.1016/j.scitotenv.2008.10.069

Pinay, G. et al., 2015. Upscaling Nitrogen Removal Capacity from Local Hotspots to Low Stream Orders' Drainage Basins. Ecosystems, 18(6): 1101-1120. 10.1007/s10021-015-9878-5

$R$ Development Core Team 2008. R: A language and environment for statistical computing. $R$ Foundation for Statistical Computing, Vienna, Austria. ISBN 3-900051-07-0, URL http://www.R-project.org.

Records, R.M., Wohl, E., Arabi, M., 2016. Phosphorus in the river corridor. Earth-Science Reviews, 158: 65-88. 10.1016/j.earscirev.2016.04.010

Richards, S., Withers, P., Patersona, E., C.W., M., Stutter, M., 2016. Temporal variability in domestic point source discharges and their associated impact on receiving waters. Science of the Total Environment, 571: 1275-1283

Serrano, T. et al., 2015. Geographical modeling of exposure risk to cyanobacteria for epidemiological purposes. Environment International, 81: 18-25. 10.1016/j.envint.2015.04.007

Sharpley, A.N., Kleinman, P.J.A., Jordan, P., Bergstrom, L., Allen, A.L., 2009. Evaluating the Success of Phosphorus Management from Field to Watershed. Journal of Environmental Quality, 38(5): 1981-1988. 10.2134/jeq2008.0056

Shore, M. et al., 2017. Influence of stormflow and baseflow phosphorus pressures on stream ecology in agricultural catchments. Science of the Total Environment, in press. 10.1016/j.scitotenv.2017.02.100

Sinaj, S. et al., 1998. Interference of colloidal particles in the determination of orthophosphate concentrations in soil water extracts. Communications in Soil Science and Plant Analysis, 29(9-10): 1091-1105. 10.1080/00103629809370011

Smith, V.H., Schindler, D.W., 2009. Eutrophication science: where do we go from here? Trends in Ecology \& Evolution, 24(4): 201-207. 10.1016/j.tree.2008.11.009

Smolders, E. et al., 2017. Internal Loading and Redox Cycling of Sediment Iron Explain Reactive Phosphorus Concentrations in Lowland Rivers. Environmental Science \& Technology

Stamm, C., Jarvie, H.P., Scott, T., 2014. What's More Important for Managing Phosphorus: Loads, Concentrations or Both? Environmental Science \& Technology, 48(1): 23-24. 10.1021/es405148c

Sucker, C., von Wilpert, K., Puhlmann, H., 2011. Acidification reversal in low mountain range streams of Germany. Environmental Monitoring and Assessment, 174(1-4): 65-89. 10.1007/s10661010-1758-z

Surridge, B.W.J., Heathwaite, A.L., Baird, A.J., 2007. The release of phosphorus to porewater and surface water from river riparian sediments. Journal of Environmental Quality, 36(5): 15341544. $10.2134 /$ jeq2006.0490 
Thomas, Z., Abbott, B., Troccaz, O., Baudry, J., Pinay, G., 2016. Proximate and ultimate controls on carbon and nutrient dynamics of small agricultural catchments. Biogeosciences, 13(6): 18631875. 10.5194/bg-13-1863-2016

van der Grift, B., Rozemeijer, J.C., Griffioen, J., van der Velde, Y., 2014. Iron oxidation kinetics and phosphate immobilization along the flow-path from groundwater into surface water. Hydrology and Earth System Sciences, 18(11): 4687-4702. 10.5194/hess-18-4687-2014

Van Moorleghem, C., Six, L., Degryse, F., Smolders, E., Merckx, R., 2011. Effect of Organic P Forms and $P$ Present in Inorganic Colloids on the Determination of Dissolved $P$ in Environmental Samples by the Diffusive Gradient in Thin Films Technique, Ion Chromatography, and Colorimetry. Analytical Chemistry, 83(13): 5317-5323. 10.1021/ac200748e

Withers, P.J.A., Jarvie, H.P., 2008. Delivery and cycling of phosphorus in rivers: A review. Science of the Total Environment, 400(1-3): 379-395. 10.1016/j.scitotenv.2008.08.002

Withers, P.J.A., Jordan, P., May, L., Jarvie, H.P., Deal, N.E., 2014a. Do septic tank systems pose a hidden threat to water quality? Frontiers in Ecology and the Environment, 12(2): 123-130. $10.1890 / 130131$

Withers, P.J.A., Neal, C., Jarvie, H.P., Doody, D.G., 2014b. Agriculture and Eutrophication: Where Do We Go from Here? Sustainability, 6(9): 5853-5875. 10.3390/su6095853

Wood, S.N., 2006. Generalized Additive Models: An Introduction with R. Chapman and Hall/CRC. Woodward, S.J.R., Stenger, R., Bidwell, V.J., 2013. Dynamic analysis of stream flow and water chemistry to infer subsurface water and nitrate fluxes in a lowland dairying catchment. Journal of Hydrology, 505: 299-311. 10.1016/j.jhydrol.2013.07.044

Zhang, Q., Ball, W.P., 2017. Improving riverine constituent concentration and flux estimation by accounting for antecedent discharge conditions. Journal of Hydrology, 547: 387-402. 


\section{Pिigure2}
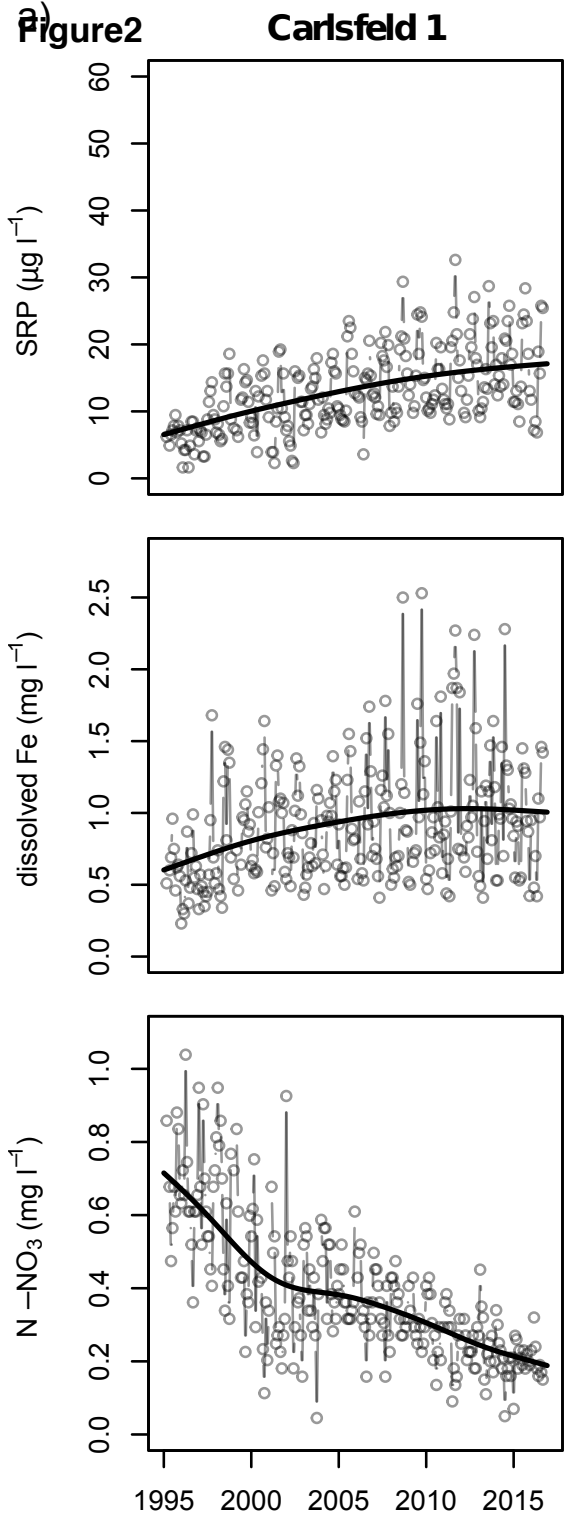

Carłsfeld 2

Carlsfeld 3
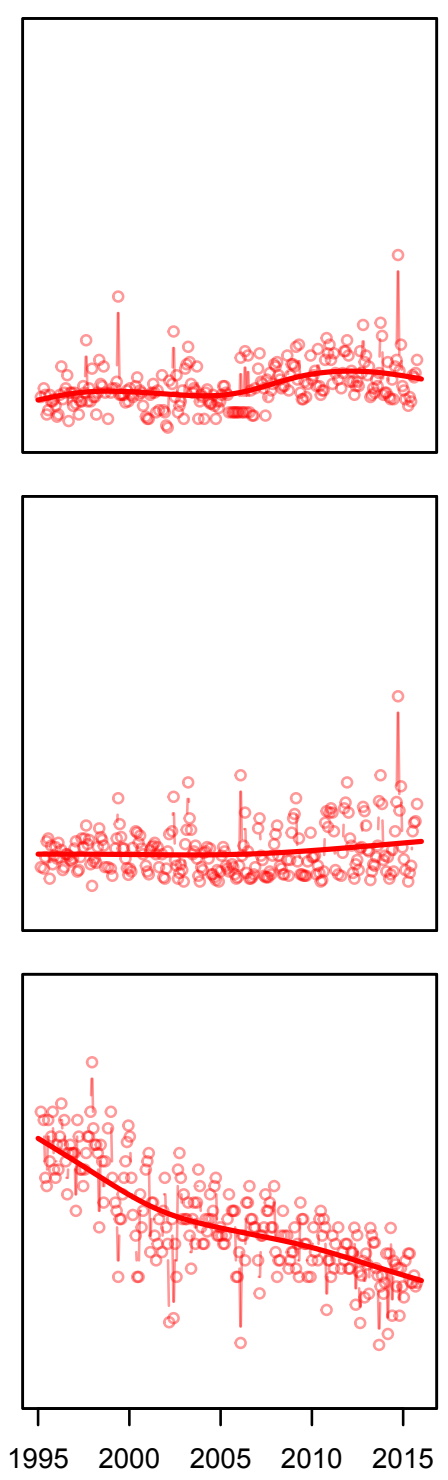

Total catchment

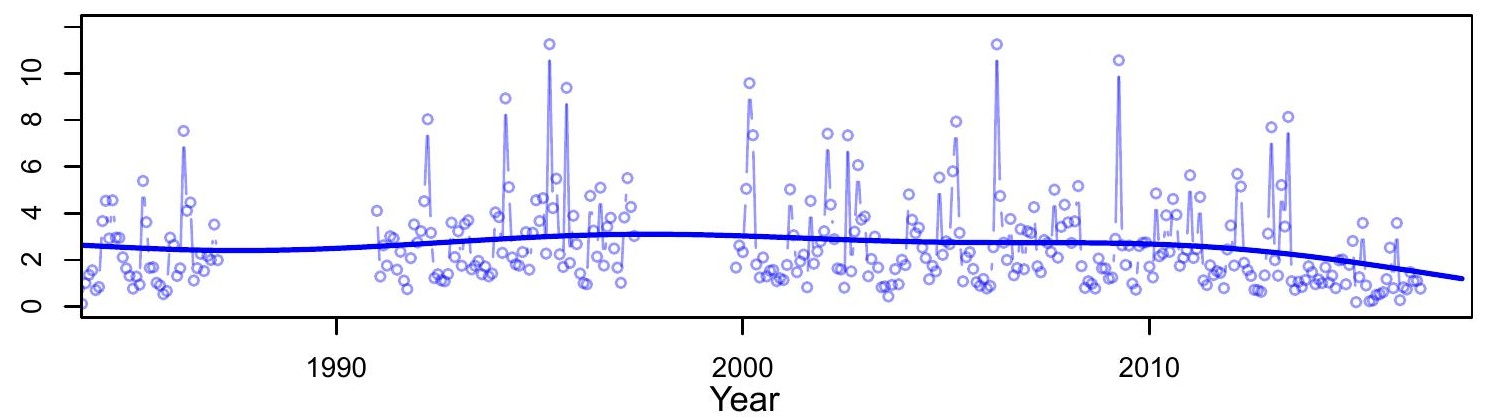

b) Seasonal component
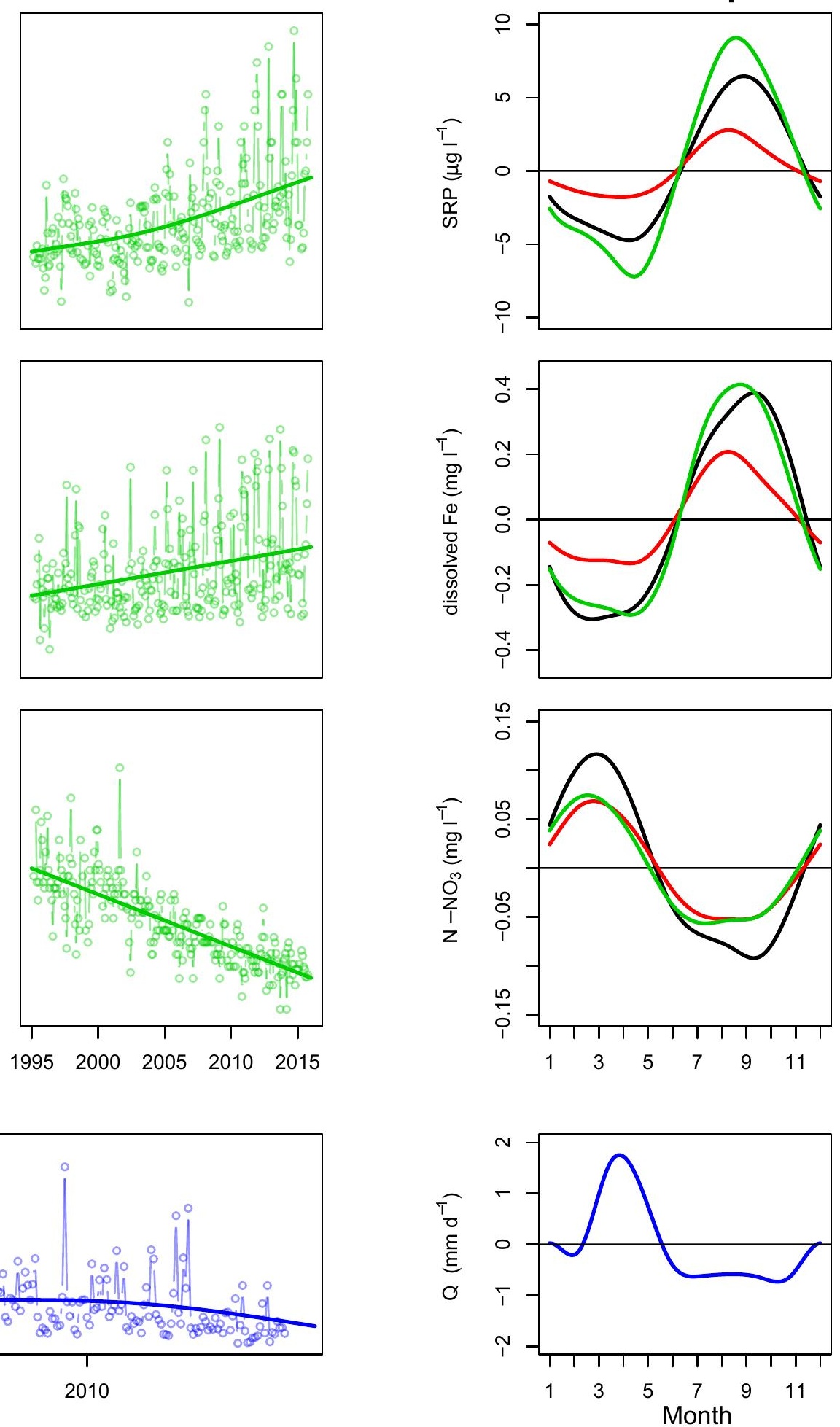
Figure3

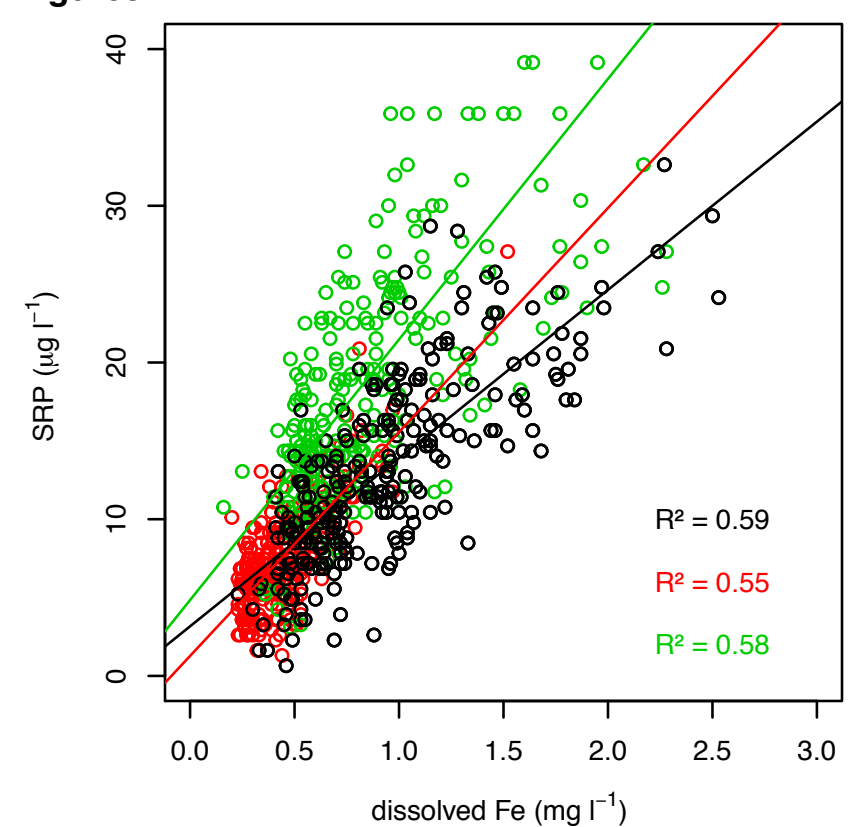

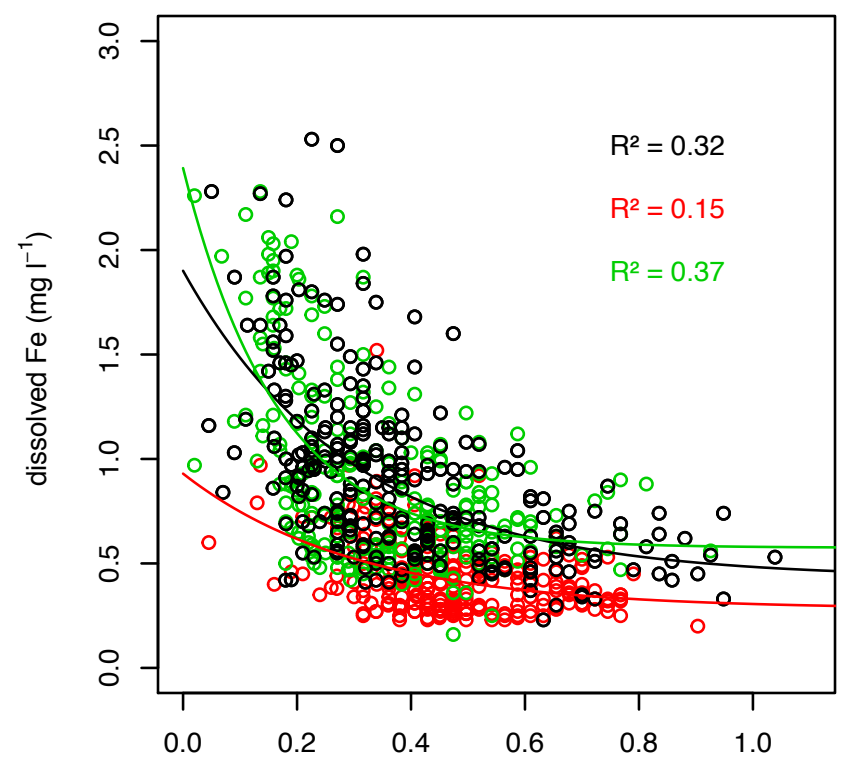

$\mathrm{N}-\mathrm{NO}_{3}\left(\mathrm{mg} \mathrm{l}^{-1}\right)$

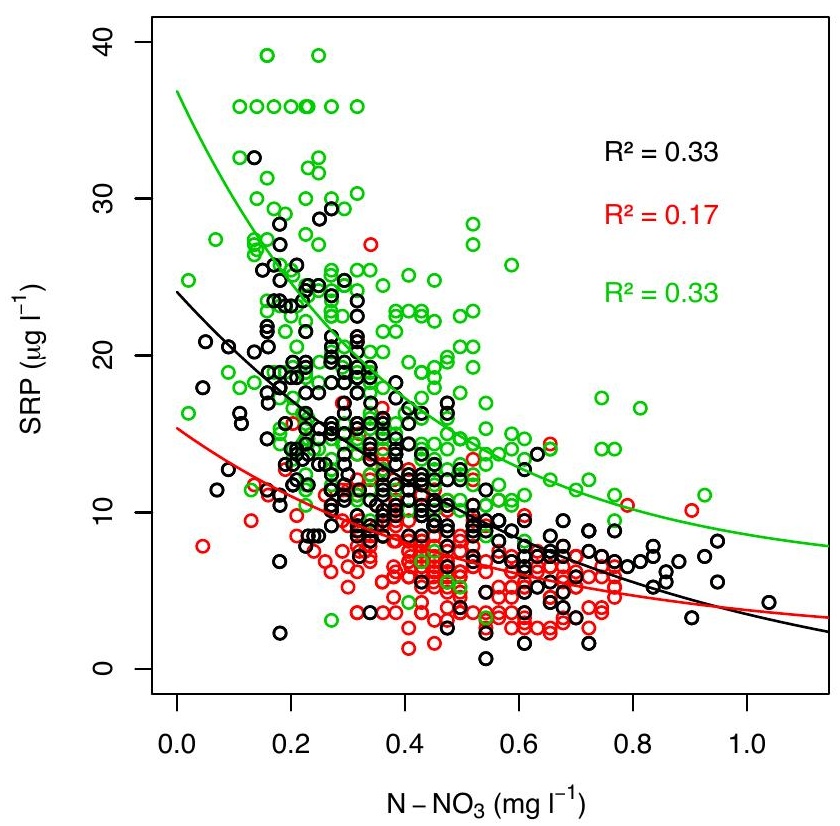




\section{Carlsfeld 1 before 2005}

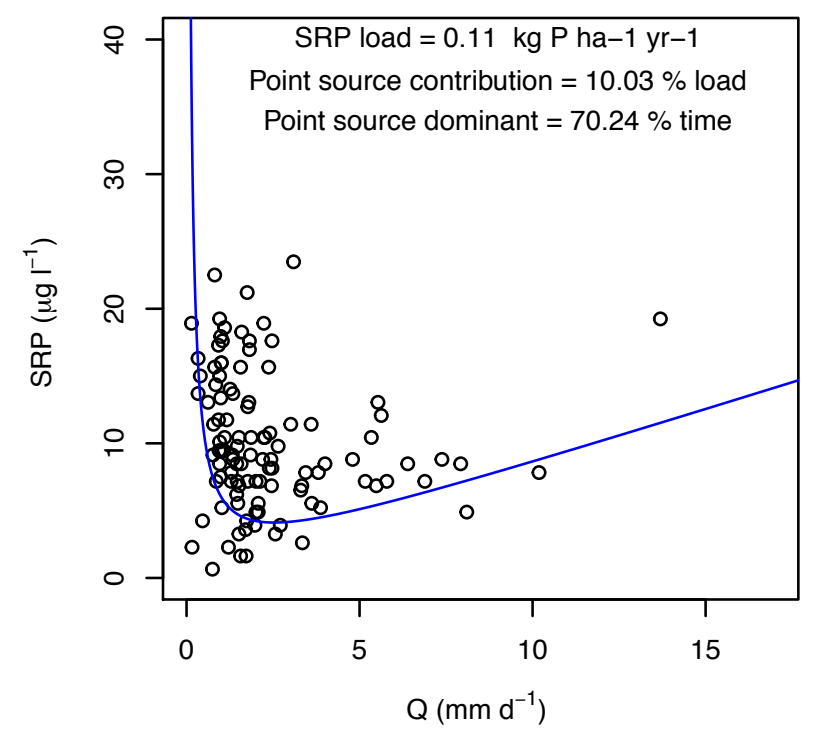

Carlsfeld 1 after 2005

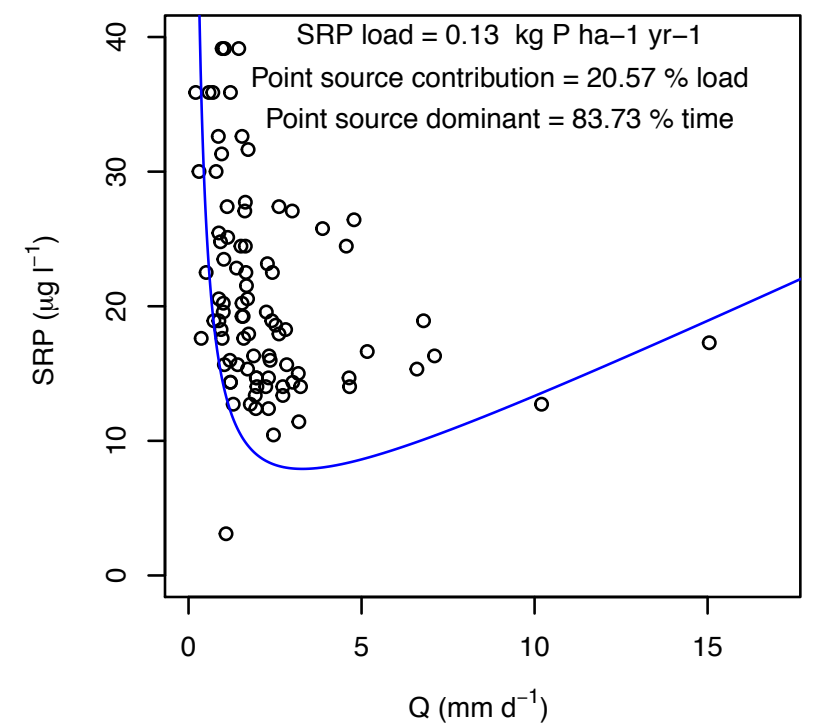

Carlsfeld 2 before 2005

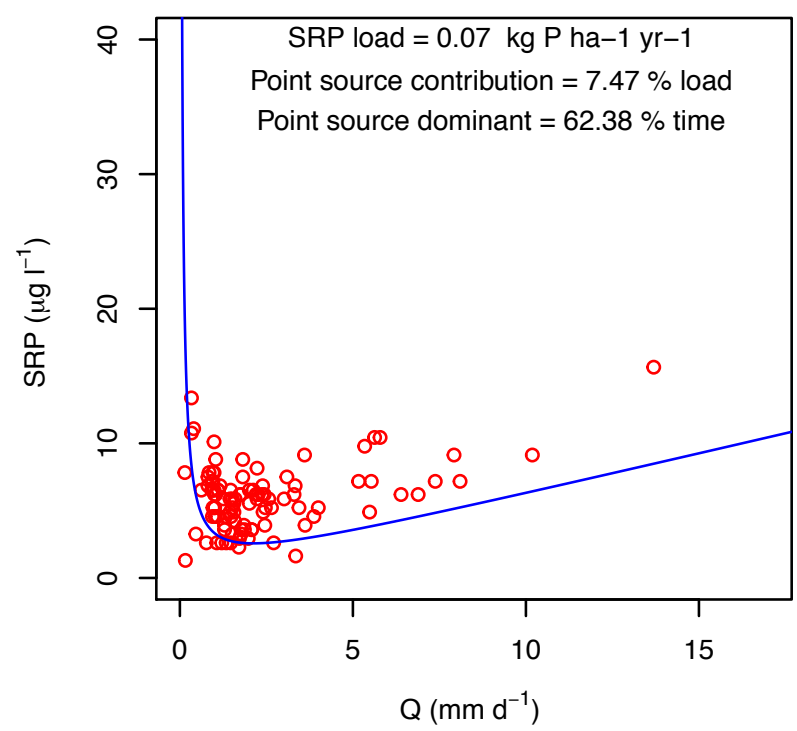

Carlsfeld 2 after 2005

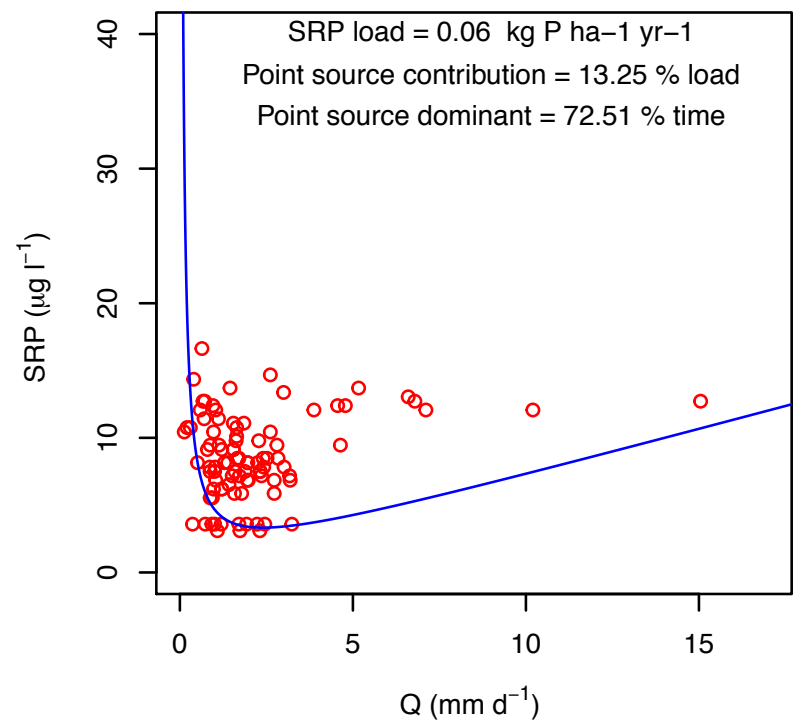

Carlsfeld 3 before 2005

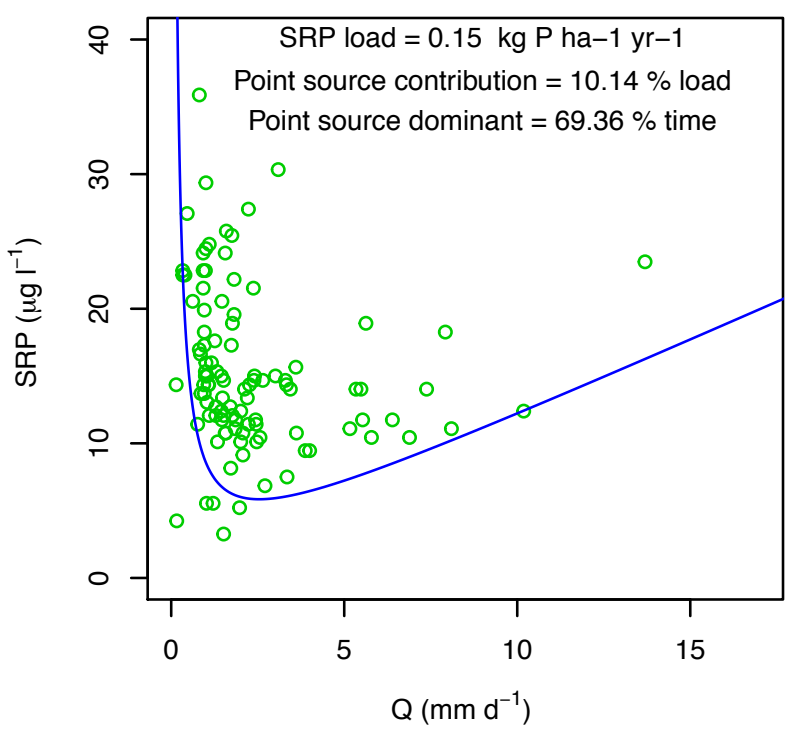

Carlsfeld 3 after 2005

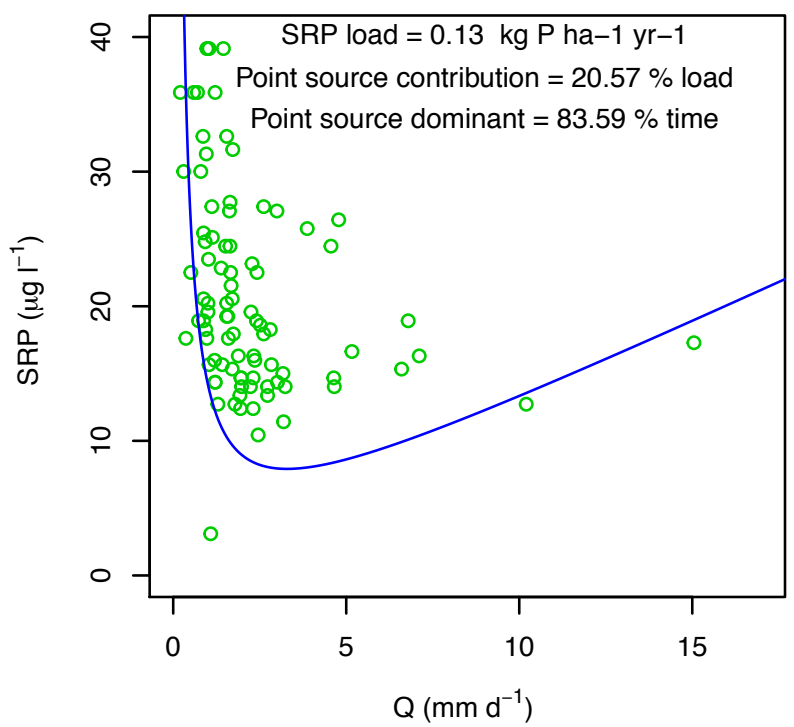



Supplementary material for on-line publication only
Click here to download Supplementary material for Click here to download Supplementary material for on-line publication only: Supplementary material.docx

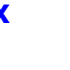

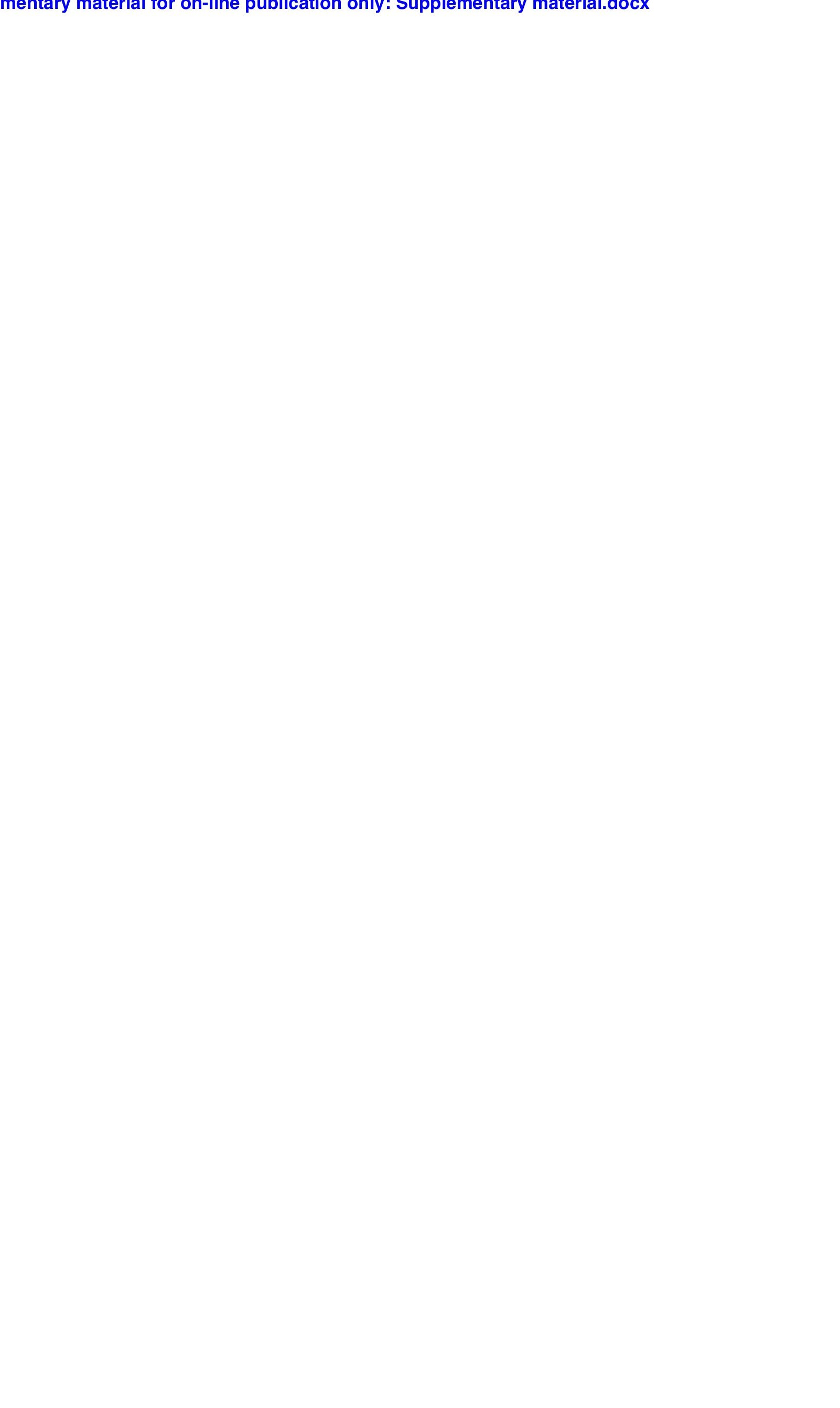

